\title{
Effect of Lactobacillus inoculants and forage dry matter on the fermentation and aerobic stability of ensiled mixed-crop tall fescue and meadow fescue
}

\author{
X. S. Guo, ${ }^{*} †$ D. J. Undersander, $\ddagger^{1}$ and D. K. Combs* \\ ${ }^{*}$ Department of Dairy Science, University of Wisconsin, Madison 53706 \\ †State Key Laboratory of Pastoral Agricultural Ecosystem, Institute of Arid Agroecology, School of Life Sciences, Lanzhou University, \\ Lanzhou 730000, China \\ ‡Department of Agronomy, University of Wisconsin, Madison 53706
}

\section{ABSTRACT}

This study evaluated the effects of Lactobacillus plantarum with or without Lactobacillus buchneri on the fermentation and aerobic stability of mixed tall fescue (Festuca arundinacea Schreb) and meadow fescue (Festuca pratensis Huds.) silage ensiled at different dry matter (DM) contents. The first cut was harvested at boot stage and second-cut grasses were harvested when 30- to $35-\mathrm{cm}$ tall. Four DM content treatments of the first cut were $17.9,24.9,34.6$, and $48.7 \%$; and of the second cut were 29.1, 36.3, 44.1, and 49.2\%. Chopped grasses at each DM content were treated with (1) deionized water (control), (2) Lb. plantarum MTD-1 (LP), or (3) a combination of $L b$. plantarum MTD1 and Lb. buchneri 40788 (LP+LB). The application amount of each inoculant to the fresh forage was $1 \times$ $10^{6} \mathrm{cfu} / \mathrm{g}$. Grasses were ensiled in vacuum-sealed polyethylene bags containing $150 \mathrm{~g}$ of DM for $60 \mathrm{~d}$, with 4 replicates for each treatment. Silages inoculated with $\mathrm{LP}+\mathrm{LB}$ had greater $\mathrm{pH}$ compared with untreated or LP-treated silages. Lactate was greater in LP silage than control or LP + LB silages. As silage DM increased, lactate in untreated and LP-treated silages decreased, but increased in LP+LB-treated silage. Acetate concentration decreased with increased DM in all silages. The LP+LB-treated silage had the longest and control silage the shortest aerobic stability for both harvests. The greatest values in aerobic stability were observed in silages with highest DM content. In this study, aerobic stability of grass mixes ensiled between 18 and $44 \%$ DM content increased as the percentage of DM increased. The LP and LP+LB inoculants improved aerobic stability of silages harvested between 18 and $44 \%$ DM content.

Key words: grass silage, Lactobacillus, fermentation quality, aerobic stability

Received May 30, 2012.

Accepted September 18, 2012.

${ }^{1}$ Corresponding author: djunders@wisc.edu

\section{INTRODUCTION}

Forage DM concentration at ensiling has substantial effects on silage fermentation, feed intake, and performance. An extensive investigation regarding effects of DM content and silage additives on the fermentation of bunker-made ryegrass silage suggested that increasing DM content from 18 to $30 \%$ without additive had beneficial influences on fermentation (Haigh et al., 1996). Feeding trials indicated that grass silages with high (44.9\%) DM concentration improved silage DMI of dairy cows (Romney et al., 2000) and milk yield of dairy cows when compared with the lower-DM alfalfa silage (Campbell and Buchanan-Smith, 1991). However, fermentation of grass silages with DM content above $40 \%$ and without addition of inoculants often results in ethanol production and high DM losses after ensiling (Xiccato et al., 1994).

To improve fermentation quality and to decrease DM losses during ensiling, homofermentative lactic acid bacteria such as Lactobacillus plantarum, Enterococcus faecium, and Pediococcus spp. are often used to promote adequate production of lactic acid and decrease in $\mathrm{pH}$. However, these inoculants did not improve (and in some cases worsened) the aerobic stability of cereal grain silages (Weinberg et al., 1993). Combination of Lb. plantarum and Lactobacillus buchneri has been shown to improve fermentation and aerobic stability of cereal grain silages (Filya, 2003b) and grass silages (Adesogan et al., 2004). Hu et al. (2009) showed that inoculation of $L b$. plantarum and $L b$. buchneri had different effects on the fermentation and aerobic stability of corn silage made at normal (33\%) and moderately (41\%) high DM content. Therefore, we proposed that $L b$. plantarum and Lb. buchneri might provide differing benefits at different moisture levels for the fermentation and aerobic stability of ensiled grasses. Few studies have been conducted to investigate the effect of $L b$. plantarum and Lb. buchneri on the fermentation and aerobic stability of grass silage when ensiled at different DM contents. 
Tall fescue (Festuca arundinacea Schreb) and meadow fescue (Festuca pratensis Huds.) are widely grown cool-season pasture and cultivated grasses in the Midwestern United States and southern Canada. Recently developed endophyte-free tall fescue and meadow fescue varieties possess several desirable agronomic traits, such as high yield, drought and disease tolerance, good compatibility when grown with alfalfa, winter hardiness, and persistency. Newer fescue cultivars also have soft texture, high nutritive value, and improved palatability compared with older varieties (Brink and Casler, 2009). Most grass silage fermentation information is on ryegrass (Lolium perenne L.) silages, with little research on fermentation of tall fescue and meadow fescue available (Kuoppala et al., 2008). Thus, the objective of current study was to investigate the contribution of $L b$. plantarum alone or in combination with $L b$. buchneri on the fermentation and aerobic stability of mixed-crop tall fescue and meadow fescue silages ensiled at different DM contents.

\section{MATERIALS AND METHODS}

\section{Forage and Ensiling}

Mix-cropped tall fescue and meadow fescue forages were harvested on June 1, 2011, at the boot stage as first-cut forage, and on August 18, 2011, at the vegetative stage (30- to $35-\mathrm{cm}$ tall) as second-cut forage from the University of Wisconsin Arlington Research Station. The stand was about $60 \%$ tall fescue and $40 \%$ meadow fescue. After harvesting with a commercial mower/ conditioner, the fresh forage was divided into 4 piles, and each pile placed on a wooden drying frame with a screen bottom. Forage on each frame was exposed to ambient temperature and sunlight and weighed from time to time to estimate the forage DM content. Our goal was to wilt subsamples of the forage to 4 moisture levels; fresh cut (approximately 20\% DM), 30\% DM, $40 \% \mathrm{DM}$, and $50 \%$ DM. The $4 \mathrm{DM}$ content treatments obtained were 17.9 (directly harvested fresh forage), $24.9,34.6$, and $48.7 \%$ for the first-cut forage. For the second-cut forage, the DM contents at ensiling were 29.1 (directly harvested fresh forage), 36.3, 44.1, and $49.2 \%$.

The fresh and wilted forages were chopped into 1.5to-2 $\mathrm{cm}$ pieces by using a paper cutter. Chopped forages of each DM treatment were then assigned to one of the following treatments: (1) untreated (deionized water), (2) Lb. plantarum MTD-1 (LP; Vita Plus Corp., Madison, WI), or (3) a combination of Lb. plantarum MTD-1 with Lb. buchneri 40788 (LP+LB; Vita Plus Corp.). The application rate of each inoculant to the fresh forage was $1 \times 10^{6} \mathrm{cfu} / \mathrm{g}$. The same application rates were applied according to the DM content of the fresh and wilted forages. All inoculants were dissolved in $500 \mathrm{~mL}$ of deionized water, and mixed thoroughly with the forages after uniform spraying onto each pile of the chopped forages. The treated forages were packed into vacuum-sealing polyethylene plastic bags (dimensions $270 \mathrm{~mm} \times 300 \mathrm{~mm}$; Embossed Food saver bag; Taizou Wenbwu Soft-Packing Color-Printing Co. Ltd., Zhejiang, China) with 2 layers and vacuum-sealed tightly. An attempt was made to conserve approximately $150 \mathrm{~g}$ of forage DM for each treatment, so for making silage from the first-cut forage, 4 replicate bags were packed with $800 \mathrm{~g}$ of fresh forage or 580,430 , or $300 \mathrm{~g}$ of wilted forages for the $24.9,34.6$, and $48.7 \%$ DM treatments, respectively; and for making second-cut forage silages, 4 replicate bags were packed with $500 \mathrm{~g}$ of fresh forage or 440,340 , or $300 \mathrm{~g}$ of wilted forages for the 36.3 , 44.1, and 49.2\% DM treatments, respectively; The silos were then stored in closed coolers (dimensions $649 \times$ $357 \times 35.9 \mathrm{~mm}$; Igloo Island Breeze 48-quart cooler; Igloo Products Corp., Katy, TX) for $60 \mathrm{~d}$ at ambient temperature $\left(20\right.$ to $\left.22^{\circ} \mathrm{C}\right)$.

\section{Chemical Analysis}

Samples of the untreated fresh and wilted forages of each DM treatment were collected before ensiling. DM content was measured by drying the samples in a forced-air oven at $65^{\circ} \mathrm{C}$ for $72 \mathrm{~h}$. Samples were then ground with a Wiley mill (1-mm screen; Thomas Scientific, Swedesboro, NJ). Ground samples were analyzed for Kjeldahl N (AOAC, 1990; method 954.01). Crude protein content was calculated as Kjeldahl $\mathrm{N} \times 6.25$. Neutral detergent fiber and acid detergent fiber concentration was determined according to the methods of Van Soest et al. (1991) using an Ankom 200 fiber analyzer (Ankom Technology Corp., Fairport, NY). Heat-stable $\alpha$-amylase and sodium sulfite were added to the NDF solution during refluxing.

After $60 \mathrm{~d}$ of ensiling, sealed bags were opened and thoroughly mixed. Dry matter recovery of the secondcut forage silages was calculated according to weight differences between the silos and DM concentrations of the fresh and ensiled material. Dry matter recovery was not calculated for the first-cut material because fresh weights were not recorded. Subsamples of the 4 replicate silos for each treatment were immediately frozen $\left(-20^{\circ} \mathrm{C}\right)$ in sealed plastic bags until further chemical analysis. The DM, NDF, and total $\mathrm{N}$ were analyzed by the methods described for the fresh and wilted forages. A 25-g sample from each silo was placed in a blender jar, diluted with distilled water to $250 \mathrm{~g}$, and macerated for $30 \mathrm{~s}$ in a high-speed blender, and then filtered through 2 layers of cheesecloth. Silage water extract $\mathrm{pH}$ 
was measured immediately using a portable $\mathrm{pH}$ meter. The filtrate was centrifuged for $15 \mathrm{~min}$ at $10,000 \times g$ at $4^{\circ} \mathrm{C}$, filtered with a dialyzer $(0.45 \mu \mathrm{m}$,$) , and then$ analyzed for VFA and lactic acid by HPLC using a Shimadzu SCL-10 AVP controller (Shimadzu Scientific Instruments, Columbia, MD) equipped with a refractive index detector (RID-10A; Dairyland Laboratories Inc., Arcadia, WI) according to Muck and Dickerson (1988). An aliquot of $10 \mathrm{~mL}(250 \mathrm{~g} / \mathrm{L}$, wt/vol $)$ TCA was added to $40 \mathrm{~mL}$ of the filtrate and the solution was allowed to stand at room temperature for $1 \mathrm{~h}$ or was held at $4^{\circ} \mathrm{C}$ overnight to precipitate the protein. The solution was then centrifuged at $18,000 \times g$ for 15 min and the supernatant was analyzed for $\mathrm{NH}_{3}-\mathrm{N}$ (Broderick and Kang, 1980). Nonfiber carbohydrate concentration in the fresh forage and silage was estimated as described by Hall (2000).

\section{Aerobic Stability Measurement}

After sampling the silages from each bag for fermentative and chemical analysis, silages from 4 replicates of each treatment were mixed thoroughly and then triplicate silage samples (350 g for each sample) were incubated in insulated mugs (1.54 L; Bubba Brands Inc., Atlanta, GA) at room temperature $\left(24 \pm 1^{\circ} \mathrm{C}\right)$. A thermocouple wire was placed in the geometric center of the silage mass, and connected to a data logger for measuring the temperature. The mug was kept uncovered and temperature of the silage mass was recorded every $8 \mathrm{~h}$ each day. Aerobic stability was defined as the amount of time after silo opening for the silage temperature to increase by $2^{\circ} \mathrm{C}$ above ambient temperature.

\section{Statistical Analysis}

Data were analyzed by using the GLM procedure of SAS (SAS Institute, 2004) according to a randomized complete block design, and the statistical model was

$$
Y_{i j k}=\mu+\alpha_{i}+b_{j}+(\alpha \times b)_{i j}+e_{i j k},
$$

where $Y_{i j k}$ is the chemical composition and fermentative characteristics of the ensiled forages, $\mu$ is the overall mean, $\alpha_{i}$ is the effect of forage DM content $i(i=1,2$, 3 , or 4$), b_{j}$ is the effect of inoculation treatments $j(j=$ $1,2$, or 3$) ;(\alpha \times b)_{i j}$ is the effect of interaction between forage DM content and inoculation treatment, and $e_{i j k}$ is the error term. Contrasts of means were constructed to evaluate the effects of treatments within the DM contents by the Tukey test (Snedecor and Cochran, 1980), and significance was declared at $P<0.05$. Parameters of the fermentation profiles $(\mathrm{pH}$, lactate, acetate, and $\mathrm{NH}_{3}-\mathrm{N}$ ) from the first-cut and second-cut forage silages
Table 1. Dry matter content and chemical composition of the firstand second-cut tall fescue and meadow fescue mixed crops at different DM contents before ensiling

\begin{tabular}{lccc}
\hline Item & $\begin{array}{c}\text { First-cut } \\
\text { forage }\end{array}$ & $\begin{array}{c}\text { Second-cut } \\
\text { forage }\end{array}$ & SEM \\
\hline $\mathrm{DM}^{1}(\%)$ & - & - & - \\
$\mathrm{CP}(\%$ of DM) & $20.6^{\mathrm{a}}$ & $13.9^{\mathrm{b}}$ & 1.32 \\
$\mathrm{NDF}(\%$ of DM) & $54.3^{\mathrm{a}}$ & $59.5^{\mathrm{b}}$ & 1.22 \\
$\mathrm{NFC}(\%$ of DM) & 13.9 & 13.7 & 0.46 \\
\hline
\end{tabular}

${ }^{\mathrm{a}, \mathrm{b}}$ Means within a row with different superscripts differed $(P<0.05)$. ${ }^{1} \mathrm{DM}$ contents for the first-cut forage at ensiling were 17.9, 24.9, 34.6, and $48.7 \%$; for the second-cut forage, DM contents were 29.1,36.3, 44.1 , and $49.2 \%$.

were plotted when inoculation $\times$ DM interactions were significant $(P<0.05)$ to aid interpretation of results.

\section{RESULTS}

\section{Fresh Intercrops of Tall Fescue and Meadow Fescue}

The chemical composition of first-cut and second-cut grasses before ensiling is shown in Table 1. The first-cut grass had lower NDF and higher CP content than the second-cut grass $(P<0.05)$, but no difference existed in NFC concentration between the first- and second-cut grasses $(P>0.05)$.

\section{Chemical Composition of Mix-Crop Tall Fescue and Meadow Fescue Silages Ensiled for $60 d$}

The main effects of inoculation and DM on the chemical composition of mix-crop tall fescue and meadow fescue silages after $60 \mathrm{~d}$ of fermentation are shown in Tables 2 and 3 for the first-cut grass silages and the second-cut grass silages, respectively. The first-cut grass silages treated with LP+LB had greater NDF and lower NFC than untreated silages and silages treated with LP $(P<0.05)$. For the second-cut grass silages, however, no effects of inoculation on these 2 variables were observed. Dry matter content had little effect on NDF concentration in the first-cut grass silages, and increased DM content increased the CP concentration but decreased the NFC concentration. In the secondcut grass silages, the lowest values in NDF and NFC concentrations were found in silages with the lowest DM content, and no differences were observed in these 2 variables among the other DM contents. Inoculation with LP or LP+LB decreased DM recovery of silages compared with untreated silages in the second-cut grass silages, and silages inoculated with $\mathrm{LP}+\mathrm{LB}$ had the lowest DM recovery $(P<0.05)$.

\section{Fermentation Characteristics of Mix-Crop Tall Fescue and Meadow Fescue Silages Ensiled for $60 \mathrm{~d}$}

Inoculation had effects on the fermentation profiles of the first-cut (Table 4) and the second-cut grass si- 
Table 2. Chemical composition of the first-cut grass silages ensiled at different DM contents for 60 d and inoculated with Lactobacillus plantarum or with Lb. plantarum plus Lactobacillus buchneri

\begin{tabular}{|c|c|c|c|c|c|c|c|c|c|c|c|c|}
\hline \multirow[b]{2}{*}{ Item } & \multicolumn{3}{|c|}{ Inoculation treatment $(\mathrm{I})^{1}$} & \multirow[b]{2}{*}{ SEM } & \multicolumn{4}{|c|}{ DM content at ensiling } & \multirow[b]{2}{*}{ SEM } & \multicolumn{3}{|c|}{ ANOVA ( $P$-value $)$} \\
\hline & Control & LP & $\mathrm{LP}+\mathrm{LB}$ & & $18 \%$ & $25 \%$ & $35 \%$ & $49 \%$ & & I & $\mathrm{DM}$ & $\mathrm{I} \times \mathrm{DM}$ \\
\hline $\mathrm{DM}(\%)$ & 30.8 & 31.0 & 31.1 & 0.23 & $17.9^{\mathrm{A}}$ & $26.4^{\mathrm{B}}$ & $34.8^{\mathrm{C}}$ & $44.7^{\mathrm{D}}$ & 0.27 & 0.72 & $<0.001$ & $<0.001$ \\
\hline $\mathrm{NDF}(\%$ of DM) & $46.6^{\mathrm{a}}$ & $47.0^{\mathrm{a}}$ & $48.1^{\mathrm{b}}$ & 0.20 & $47.2^{\mathrm{AB}}$ & $46.6^{\mathrm{A}}$ & $47.7^{\mathrm{B}}$ & $47.4^{\mathrm{B}}$ & 0.24 & $<0.001$ & 0.015 & $<0.001$ \\
\hline $\mathrm{NFC}(\%$ of DM) & $22.5^{\mathrm{b}}$ & $22.0^{\mathrm{b}}$ & $21.1^{\mathrm{a}}$ & 0.17 & $22.8^{\mathrm{B}}$ & $22.4^{\mathrm{B}}$ & $21.0^{\mathrm{A}}$ & $21.2^{\mathrm{A}}$ & 0.20 & $<0.001$ & $<0.001$ & $<0.001$ \\
\hline
\end{tabular}

${ }^{\mathrm{A}-\mathrm{D}}$ Means of DM content at ensiling within a row with different superscripts differ $(P<0.05)$.

${ }^{\mathrm{a}, \mathrm{b}}$ Means of inoculation treatment within a row with different superscripts differ $(P<0.05)$.

${ }^{1} \mathrm{LP}=$ Lb. plantarum MTD-1; LP $+\mathrm{LB}=\mathrm{LP}$ plus Lb. buchneri 40788.

lages (Table 5). For the first-cut grass silages, silage inoculated with LP had lower $\mathrm{pH}$ than untreated silage and silage treated with $\mathrm{LP}+\mathrm{LB}(P<0.05)$. The inoculated silages had greater concentrations of $\mathrm{NH}_{3}-\mathrm{N}$ compared with untreated silage $(P<0.05)$, and the highest concentration of $\mathrm{NH}_{3}-\mathrm{N}$ was found in $\mathrm{LP}+\mathrm{LB}$-treated silage $(P<0.05)$. For the second-cut silages, however, grass treated with $\mathrm{LP}$ had lower $\mathrm{NH}_{3}-\mathrm{N}$ concentration than untreated or LP+LB-treated silages $(P<0.05)$, and no difference existed in $\mathrm{NH}_{3}-\mathrm{N}$ concentration between untreated silage and silage treated with LP+LB. Silages made from the first-cut and second-cut grasses and inoculated with LP had greater concentrations of lactate and total acid than silage treated with LP $+\mathrm{LB}$ and untreated silage in the first-cut silage $(P<0.05)$. The lowest concentration of lactate and the greatest concentration of acetate occurred in $\mathrm{LP}+\mathrm{LB}$-treated silages $(P<0.05)$. The total acid concentration in LP-treated silage was greater than that in untreated silage in the first-cut grass silages $(P<0.05)$, but no difference was found in the second-cut grass silages, and the lowest total acid concentrations occurred both in the first-cut and second-cut grass silages $(P<0.05)$. Concentrations of propionate, butyrate, and ethanol in all samples were less than $0.01 \%$ DM (data not shown). Inoculation markedly increased aerobic stability of the ensiled mixed crops, and the silage inoculated with
LP + LB had the longest aerobic stability $(P<0.05)$ among the untreated silage and silages treated with LP and $\mathrm{LP}+\mathrm{LB}$.

Dry matter contents had different effects on $\mathrm{pH}$ values of the first-cut and second-cut grass silages. With an increase in $\mathrm{DM}$ content, the $\mathrm{pH}$ value increased in the first-cut silages (Table 4). A decrease was, however, observed in $\mathrm{pH}$ with increasing $\mathrm{DM}$ content in the second-cut grass silages (Table 5 and Figure 1). Concentrations of $\mathrm{NH}_{3}-\mathrm{N}$ and acetate in silages made from both harvests decreased as the DM increased (Tables 4 and 5; Figures 2 and 3). Acetate and $\mathrm{NH}_{3}-\mathrm{N}$ were markedly lower in silages with the highest DM content compared with the unwilted silage $(P<0.05)$. Lactate concentration in the first-cut grass silages decreased with the increase in DM content, but no difference was found in lactate concentration among DM contents of the second-cut grass silages. However, plotting figures on interactions between lactate concentrations and DM contents showed that with the increase in DM content, lactate in untreated and LP-treated silages decreased, but increased in LP+LB-treated silage (Figure 4).

Inoculants markedly improved the aerobic stability of ensiled grasses compared with the untreated silage, and the greatest value of aerobic stability was found in $\mathrm{LP}+\mathrm{LB}$-treated silage $(P<0.05)$. Interactions were observed between inoculation and forage DM contents

Table 3. Chemical composition of the second-cut grass silages ensiled at different DM contents for 60 d and inoculated with Lactobacillus plantarum or with Lb. plantarum plus Lactobacillus buchneri

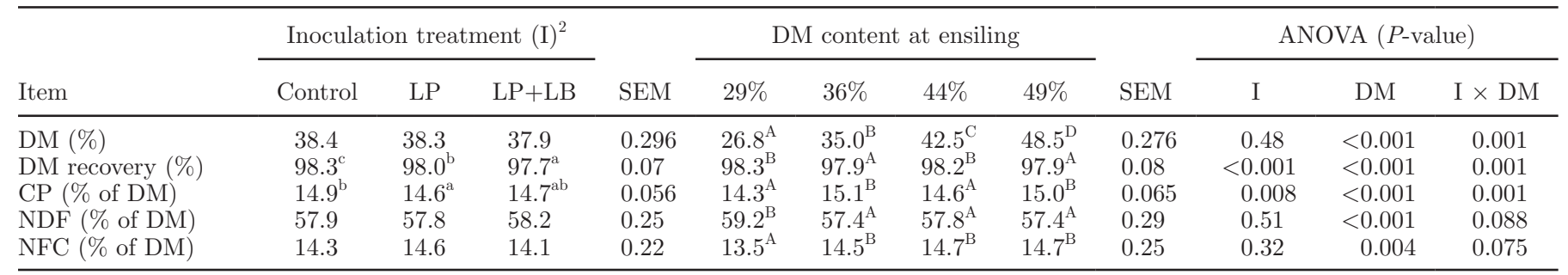

\footnotetext{
${ }^{\mathrm{A}-\mathrm{D}}$ Means of DM content at ensiling within a row with different superscripts differ $(P<0.05)$

${ }^{\text {a-c } M e a n s ~ o f ~ i n o c u l a t i o n ~ t r e a t m e n t ~ w i t h i n ~ a ~ r o w ~ w i t h ~ d i f f e r e n t ~ s u p e r s c r i p t s ~ d i f f e r ~}(P<0.05)$.

${ }^{2} \mathrm{LP}=$ Lb. plantarum MTD-1; LP $+\mathrm{LB}=\mathrm{LP}$ plus Lb. buchneri 40788.
} 
Table 4. Fermentation profiles of the first-cut grass silages ensiled at different DM contents for $60 \mathrm{~d}$ and inoculated with Lactobacillus plantarum or with Lb. plantarum plus Lactobacillus buchneri ${ }^{1}$

\begin{tabular}{|c|c|c|c|c|c|c|c|c|c|c|c|c|}
\hline \multirow[b]{2}{*}{ Item } & \multicolumn{3}{|c|}{ Inoculation treatment $(\mathrm{I})^{2}$} & \multirow[b]{2}{*}{ SEM } & \multicolumn{4}{|c|}{ DM content at ensiling } & \multirow[b]{2}{*}{ SEM } & \multicolumn{3}{|c|}{ ANOVA ( $P$-value $)$} \\
\hline & Control & LP & $\mathrm{LP}+\mathrm{LB}$ & & $18 \%$ & $25 \%$ & $35 \%$ & $49 \%$ & & I & $\mathrm{DM}$ & $\mathrm{I} \times \mathrm{DM}$ \\
\hline $\mathrm{pH}$ & $5.04^{\mathrm{b}}$ & $4.86^{\mathrm{a}}$ & $5.07^{\mathrm{b}}$ & 0.019 & $4.83^{\mathrm{A}}$ & $4.93^{\mathrm{B}}$ & $5.09^{\mathrm{C}}$ & $5.10^{\mathrm{C}}$ & 0.022 & $<0.001$ & $<0.001$ & $<0.001$ \\
\hline $\mathrm{NH}_{3}-\mathrm{N}(\%$ of total $\mathrm{N})$ & $18.4^{\mathrm{a}}$ & $22.6^{\mathrm{b}}$ & $25.8^{\mathrm{c}}$ & 0.52 & $24.2^{\mathrm{B}}$ & $24.7^{\mathrm{B}}$ & $23.1^{\mathrm{B}}$ & $17.1^{\mathrm{A}}$ & 0.60 & $<0.001$ & $<0.001$ & $<0.001$ \\
\hline Lactate $(\%$ of $\mathrm{DM})$ & $3.75^{\mathrm{b}}$ & $5.25^{\mathrm{c}}$ & $2.84^{\mathrm{a}}$ & 0.155 & $5.59^{\mathrm{C}}$ & $4.25^{\mathrm{B}}$ & $2.89^{\mathrm{A}}$ & $3.05^{\mathrm{A}}$ & 0.179 & $<0.001$ & $<0.001$ & $<0.001$ \\
\hline Acetate $(\%$ of DM) & $1.89^{\mathrm{a}}$ & $2.35^{\mathrm{b}}$ & $3.32^{\mathrm{c}}$ & 0.085 & $4.59^{\mathrm{D}}$ & $2.54^{\mathrm{C}}$ & $1.73^{\mathrm{B}}$ & $1.23^{\mathrm{A}}$ & 0.098 & $<0.001$ & $<0.001$ & $<0.001$ \\
\hline Total acid (\% of DM) & $5.64^{\mathrm{a}}$ & $7.60^{\mathrm{c}}$ & $6.43^{\mathrm{b}}$ & 0.221 & $10.57^{\mathrm{C}}$ & $6.79^{\mathrm{B}}$ & $4.62^{\mathrm{A}}$ & $4.27^{\mathrm{A}}$ & 0.256 & $<0.001$ & $<0.001$ & $<0.001$ \\
\hline Lactate/total acid & $66.9^{\mathrm{b}}$ & $69.4^{\mathrm{c}}$ & $49.4^{\mathrm{a}}$ & 0.65 & $51.9^{\mathrm{A}}$ & $61.9^{\mathrm{B}}$ & $62.3^{\mathrm{B}}$ & $71.5^{\mathrm{C}}$ & 0.75 & $<0.001$ & $<0.001$ & $<0.001$ \\
\hline Aerobic stability $^{3}(\mathrm{~h})$ & $261^{\mathrm{a}}$ & $370^{\mathrm{b}}$ & $410^{\mathrm{c}}$ & 5.9 & $367^{\mathrm{C}}$ & $242^{\mathrm{A}}$ & $269^{\mathrm{B}}$ & $508^{\mathrm{D}}$ & 6.8 & $<0.001$ & $<0.001$ & $<0.001$ \\
\hline
\end{tabular}

${ }^{\mathrm{a}-c}$ Means of inoculation treatment within a row with different superscripts differ $(P<0.05)$.

${ }^{\mathrm{A}-\mathrm{D}}$ Means of DM content at ensiling within a row with different superscripts differ $(P<0.05)$.

${ }^{1}$ Concentrations of propionate, butyrate, and ethanol in all treatments were less than $0.01 \%$ of DM.

${ }^{2} \mathrm{LP}=$ Lb. plantarum MTD-1; LP+LB = LP plus Lb. buchneri 40788.

${ }^{3}$ Defined as hours after opening for silage temperature to increase by $2^{\circ} \mathrm{C}$ above ambient temperature. Forages ensiled at $49 \%$ DM dried out before temperature of material increased

$2^{\circ} \mathrm{C}$; therefore, values reported for this treatment are time to increase $1^{\circ} \mathrm{C}$ above ambient temperature.

Table 5. Fermentation profiles of second-cut grass silages ensiled at different DM contents for $60 \mathrm{~d}$ and inoculated with Lactobacillus plantarum or with Lb. plantarum plus Lactobacillus buchneri ${ }^{1}$

\begin{tabular}{|c|c|c|c|c|c|c|c|c|c|c|c|c|}
\hline \multirow[b]{2}{*}{ Item } & \multicolumn{3}{|c|}{ Inoculation treatment $(\mathrm{I})^{2}$} & \multirow[b]{2}{*}{ SEM } & \multicolumn{4}{|c|}{ DM content at ensiling } & \multirow[b]{2}{*}{ SEM } & \multicolumn{3}{|c|}{ ANOVA ( $P$-value $)$} \\
\hline & Control & LP & $\mathrm{LP}+\mathrm{LB}$ & & $29 \%$ & $36 \%$ & $44 \%$ & $49 \%$ & & I & $\mathrm{DM}$ & $\mathrm{I} \times \mathrm{DM}$ \\
\hline $\begin{array}{l}\mathrm{pH}^{\mathrm{pH}} \\
\mathrm{NH}_{3} \mathrm{~N}(\% \text { of total N) } \\
\text { Lactate }(\% \text { of DM) } \\
\text { Acetate }(\% \text { of DM) } \\
\text { Total acid }(\% \text { of DM) } \\
\text { Lactate/total acid } \\
\text { Aerobic stability }{ }^{3}(\mathrm{~h})\end{array}$ & $\begin{array}{c}4.63^{\mathrm{a}} \\
10.4^{\mathrm{b}} \\
5.04^{\mathrm{b}} \\
1.29^{\mathrm{b}} \\
6.51^{\mathrm{b}} \\
78.9^{\mathrm{b}} \\
417^{\mathrm{a}}\end{array}$ & $\begin{array}{c}4.58^{\mathrm{a}} \\
9.8^{\mathrm{a}} \\
5.13^{\mathrm{b}} \\
0.89^{\mathrm{a}} \\
6.59^{\mathrm{b}} \\
81.6^{\mathrm{c}} \\
434^{\mathrm{b}}\end{array}$ & $\begin{array}{c}4.74^{\mathrm{b}} \\
10.3^{\mathrm{b}} \\
3.62^{\mathrm{a}} \\
1.41^{\mathrm{c}} \\
5.44^{\mathrm{a}} \\
67.5^{\mathrm{a}} \\
587^{\mathrm{c}}\end{array}$ & $\begin{array}{l}0.027 \\
0.16 \\
0.190 \\
0.060 \\
0.264 \\
0.691 \\
2.2\end{array}$ & $\begin{array}{c}4.83^{\mathrm{C}} \\
12.5^{\mathrm{D}} \\
4.72 \\
1.57^{\mathrm{B}} \\
7.49^{\mathrm{D}} \\
61.4^{\mathrm{A}} \\
518^{\mathrm{C}}\end{array}$ & $\begin{array}{c}4.73^{\mathrm{B}} \\
11.0^{\mathrm{C}} \\
4.55 \\
1.66^{\mathrm{B}} \\
6.52^{\mathrm{C}} \\
71.6^{\mathrm{B}} \\
480^{\mathrm{B}}\end{array}$ & $\begin{array}{c}4.48^{\mathrm{A}} \\
9.2^{\mathrm{B}} \\
4.58 \\
0.86^{\mathrm{A}} \\
5.46^{\mathrm{A}} \\
83.7^{\mathrm{C}} \\
397^{\mathrm{A}}\end{array}$ & $\begin{array}{c}4.56^{\mathrm{A}} \\
8.0^{\mathrm{A}} \\
4.53 \\
0.71^{\mathrm{A}} \\
5.24^{\mathrm{A}} \\
87.2^{\mathrm{D}} \\
523^{\mathrm{C}}\end{array}$ & $\begin{array}{l}0.032 \\
0.18 \\
0.220 \\
0.069 \\
0.277 \\
0.797 \\
2.5\end{array}$ & $\begin{array}{r}0.001 \\
0.048 \\
<0.001 \\
<0.001 \\
0.002 \\
<0.001 \\
<0.001\end{array}$ & $\begin{array}{l}<0.001 \\
<0.001 \\
0.92 \\
<0.001 \\
<0.001 \\
<0.001 \\
<0.001\end{array}$ & $\begin{array}{r}0.002 \\
<0.001 \\
0.001 \\
0.001 \\
0.26 \\
<0.001 \\
<0.001\end{array}$ \\
\hline $\begin{array}{l}{ }^{\mathrm{a}-\mathrm{C}} \text { Means of inoculation } \\
\mathrm{A}-\mathrm{D} \text { Means of DM conte } \\
{ }^{1} \text { Concentrations of pro } \\
{ }^{2} \mathrm{LP}=\mathrm{L} \text {. plantarum } \\
{ }^{3} \text { Defined as hours after } \\
2^{\circ} \mathrm{C} \text {; therefore, values } \mathrm{r}\end{array}$ & $\begin{array}{l}\text { ent within } \\
\text { siling witl } \\
\text { butyrate, } \\
\mathrm{LP}+\mathrm{LB}= \\
\mathrm{g} \text { for silage } \\
\text { for this t }\end{array}$ & $\begin{array}{l}\text { a row wit } \\
\text { d ethanol } \\
\text { P plus } L b \\
\text { mperature } \\
\text { ment are }\end{array}$ & $\begin{array}{l}\text { different } \mathrm{s} \\
\text { all treatn } \\
\text { uchneri } 40 \\
\text { o increase } \\
\text { me to incr }\end{array}$ & $\begin{array}{l}\text { erscripts } \\
\text { its were } \\
8 \text {. } \\
2^{\circ} \mathrm{C} \text { abo } \\
\text { se } 1^{\circ} \mathrm{C} \text { al }\end{array}$ & $\begin{array}{l}\text { ( }(P<0.0 \\
\text { fer }(P<0 \\
\text { than } 0.01 \\
\text { ambient te } \\
\text { e ambient }\end{array}$ & $\begin{array}{l}\text { DM. } \\
\text { erature. Fr } \\
\text { perature. }\end{array}$ & ses ensiled & $49 \% \mathrm{DM}$ & out b & e temper & e of ma & al increased \\
\hline
\end{tabular}



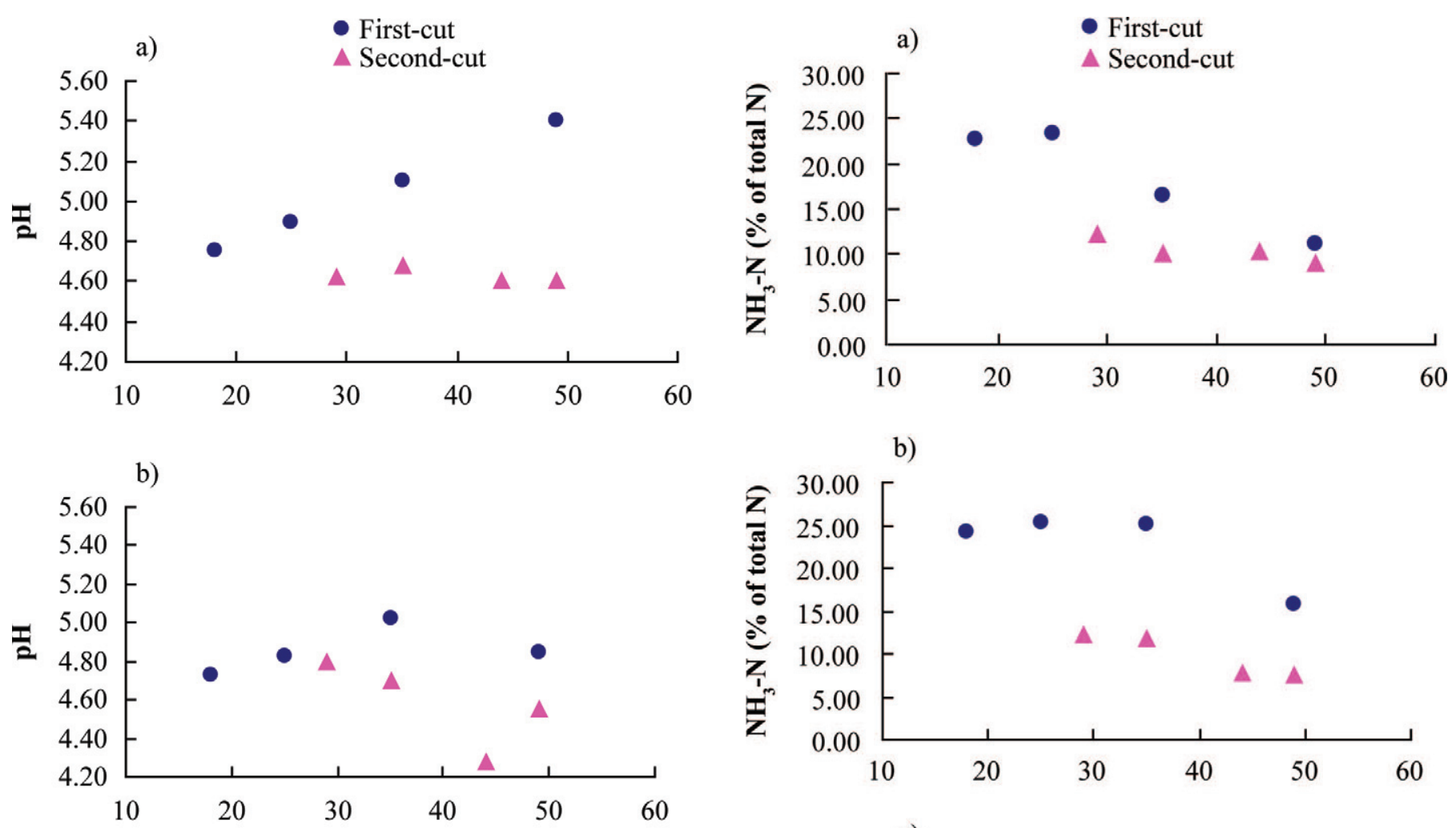

b)
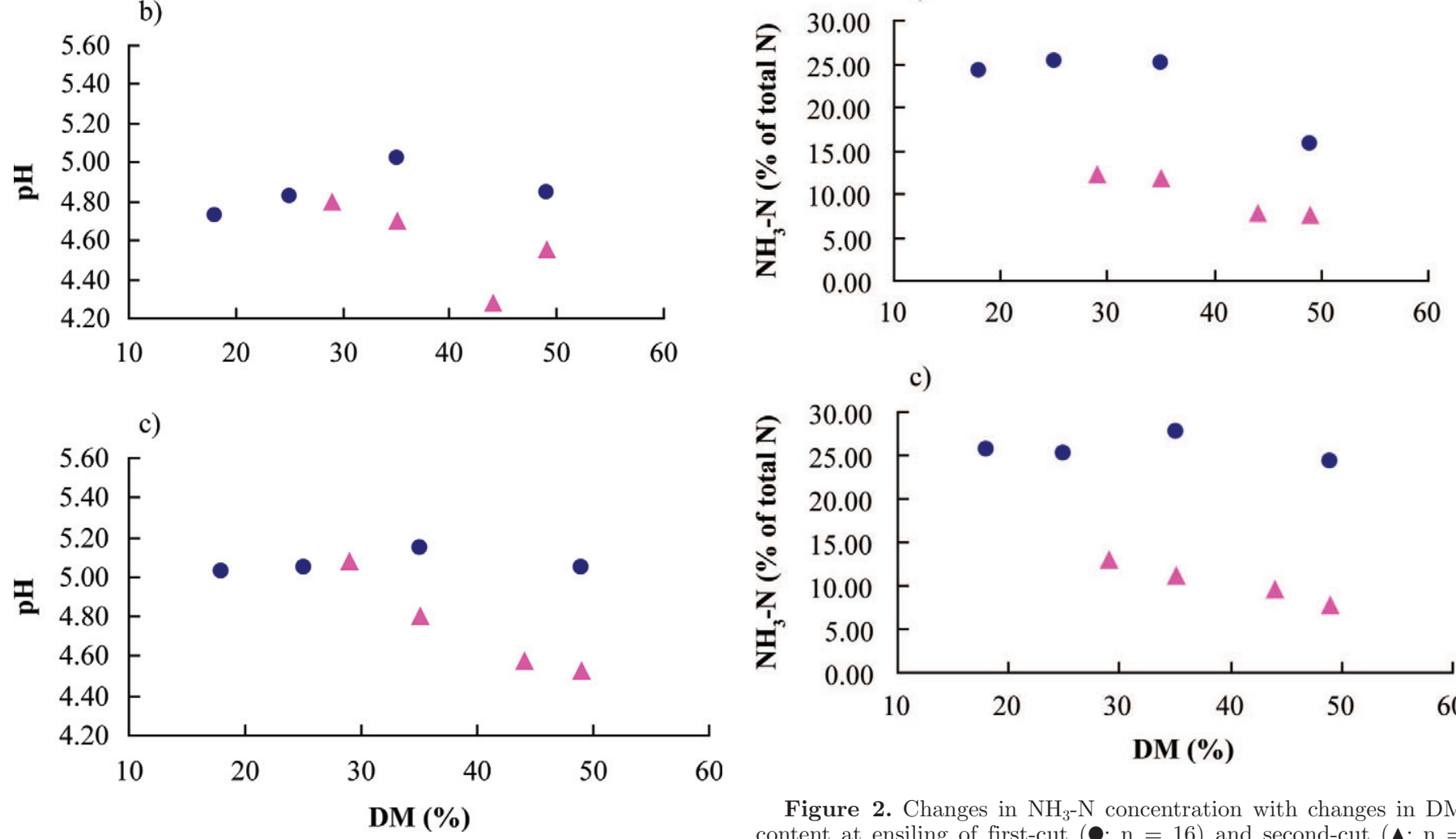

Figure 1. Changes in $\mathrm{pH}$ with changes in DM content at ensiling of the first-cut $(\mathbf{\bullet} ; \mathrm{n}=16)$ and the second-cut $(\boldsymbol{\Delta} ; \mathrm{n}=16)$ tall fescue and meadow fescue mixed-crop silages treated without inoculation (control; a), with Lactobacillus plantarum (b), or with Lb. plantarum and Lactobacillus buchneri (c). Color version available in the online PDF.

on aerobic stability of the ensiled mixed crops $(P<$ $0.001)$. Aerobic stability of mixed grasses ensiled between 18 to $44 \%$ DM increased as the DM content increased (Tables 4 and 5). In both cuttings, the silages with the highest DM content dried out before reaching the predetermined $2^{\circ} \mathrm{C}$ rise above ambient temperature.

\section{DISCUSSION}

Different effects of inoculation or forage DM on concentrations of $\mathrm{CP}, \mathrm{NDF}$, and $\mathrm{NFC}$ occurred between

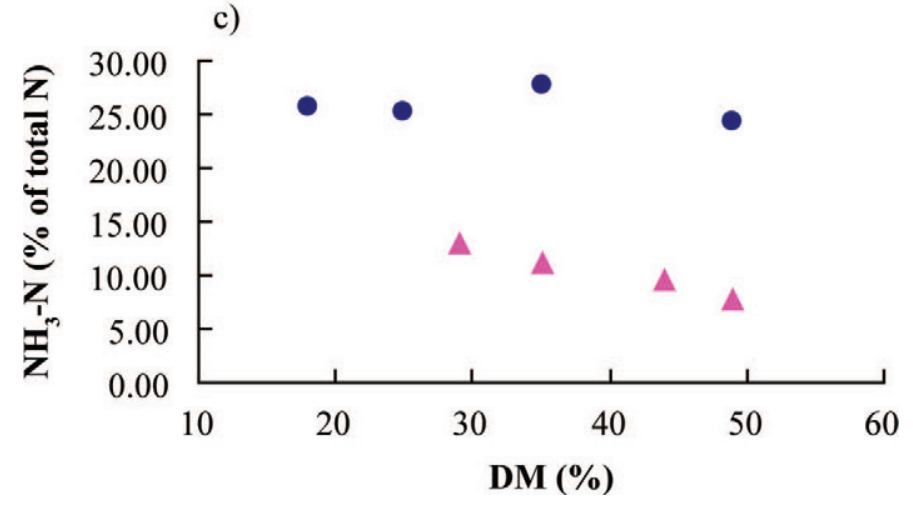

Figure 2. Changes in $\mathrm{NH}_{3}-\mathrm{N}$ concentration with changes in $\mathrm{DM}$ content at ensiling of first-cut $(\mathbf{\bullet} ;=16)$ and second-cut $(\mathbf{\Lambda} ; \mathrm{n}=$ 16) tall fescue and meadow fescue mixed-crop silages treated without inoculation (control; a), with Lactobacillus plantarum (b), or with $L b$. plantarum and Lactobacillus buchneri (c). Color version available in the online PDF.

the first-cut and the second-cut grass silages. Lower NFC concentration in the LP+LB-treated silage than in untreated or LP-treated first-cut silage was probably due to heterofermentative bacteria of Lb. buchneri consuming more nutrients for fermentation than homofermentative bacteria (Oude Elferink et al., 1999), which consequently caused a greater NDF concentration on a $\mathrm{DM}$ basis in the LP+LB-treated silage. Although the concentration of $\mathrm{CP}$ in the LP-treated silage made from second-cut grass was statistically lower than untreated silage, this difference was small and not of practical sig- 


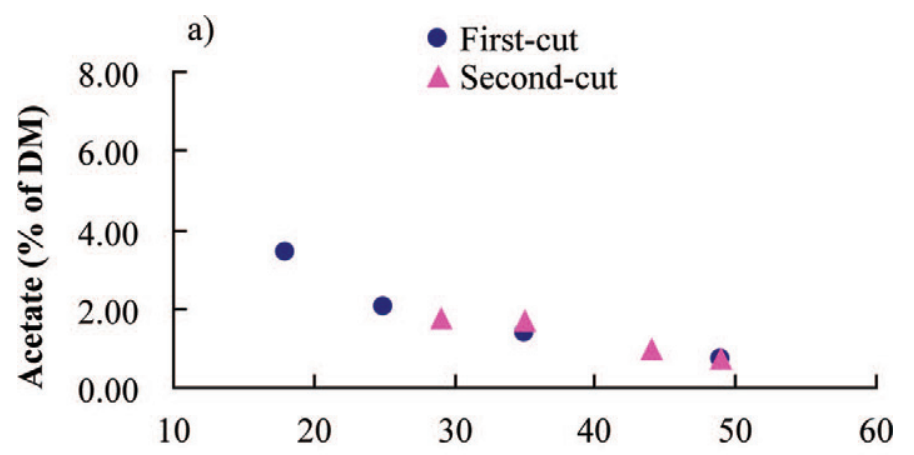

b)

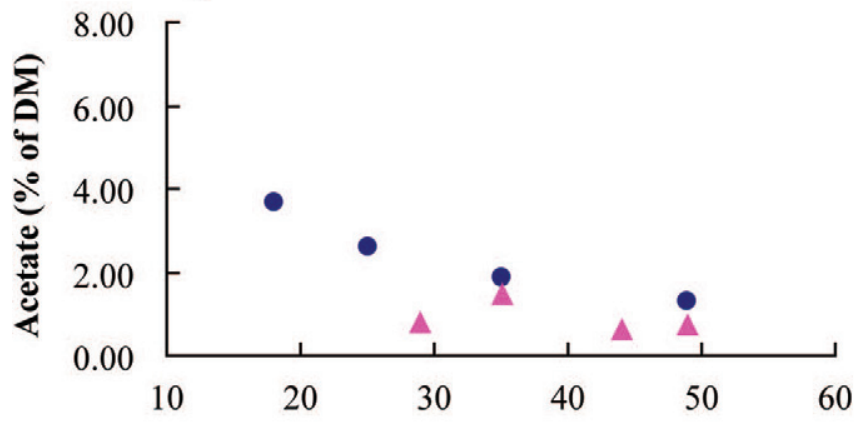

c)

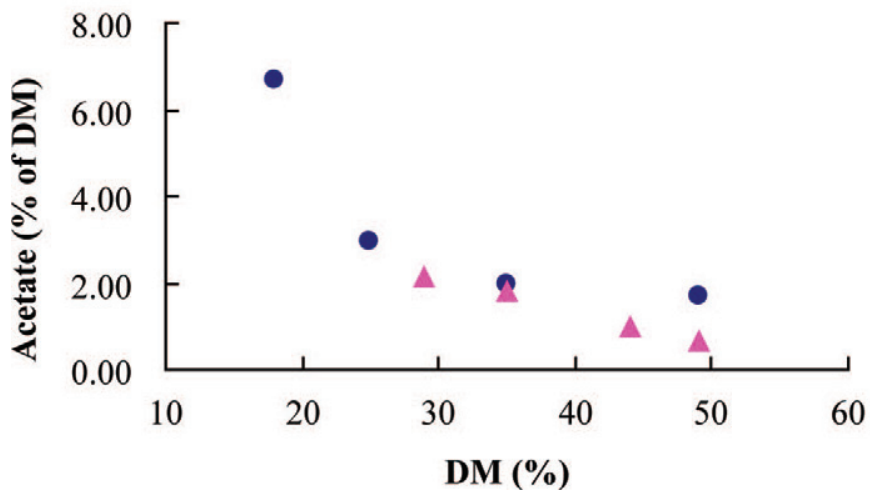

Figure 3. Changes in acetate concentration with changes in DM content at ensiling of first-cut $(\boldsymbol{O} ; \mathrm{n}=16)$ and second-cut $(\boldsymbol{\Delta} ; \mathrm{n}=$ 16) tall fescue and meadow fescue mixed-crop silages treated without inoculation (control; a), with Lactobacillus plantarum (b), or with Lb. plantarum and Lactobacillus buchneri (c). Color version available in the online PDF.

nificance (14.9 vs. $14.6 \%)$. Effects were observed of forage DM on the $\mathrm{CP}$ and NDF concentrations in silages made from both harvests, but the difference were small.

The average concentration of NDF in the first-cut grass silage decreased about $7 \%$ after ensiling (54.3 vs. $47.2 \% \mathrm{DM})$, and the average concentration of NFC increased about $8 \%$ after ensiling (13.9 vs. $21.9 \%$ $\mathrm{DM})$. However, concentrations of the 2 variables were comparable in the second-cut grass before and after ensiling (59.5 vs. $58.0 \%$ DM for NDF; 14.3 vs. $13.7 \%$

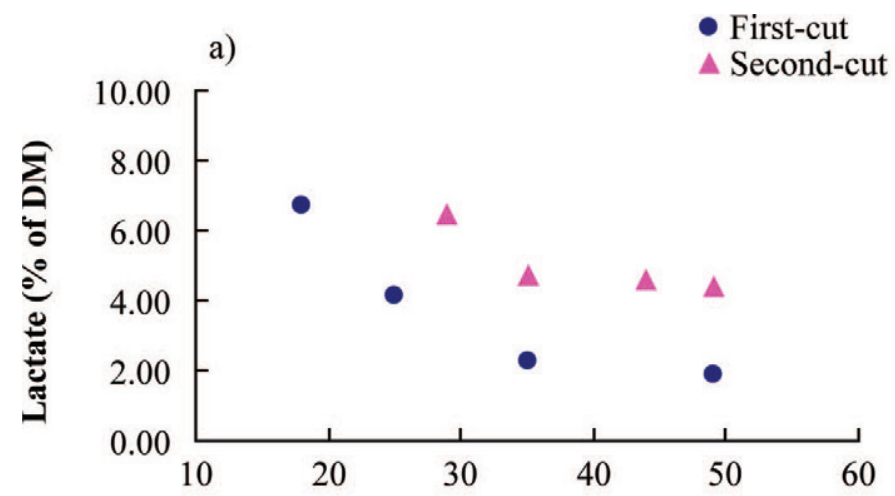

b)

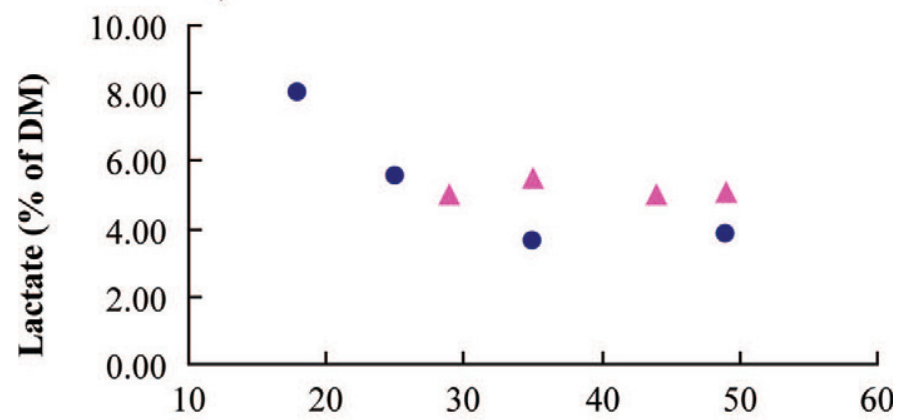

c)

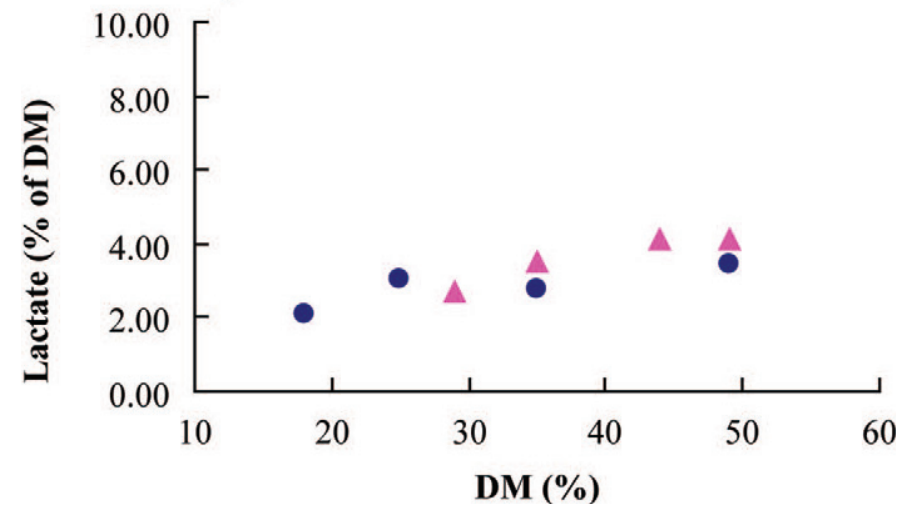

Figure 4. Changes in lactate concentration with changes in DM content at ensiling of first-cut $(\mathbf{\bullet} \mathrm{n}=16)$ and second-cut $(\boldsymbol{\Delta} ; \mathrm{n}=$ 16) tall fescue and meadow fescue mixed-crop silages treated without inoculation (control; a), with Lactobacillus plantarum (b), or with Lb. plantarum and Lactobacillus buchneri (c). Color version available in the online PDF.

DM for NFC). These findings suggest that structural carbohydrates (i.e., hemicellulose) in the first-cut grass were more degradable than the second-cut grass and thereafter transformed into NFC after fermentation. Grasses grown in a cooler environment generally have lower NDF and less lignification than grasses grown under warm conditions (Chatterton et al., 1989; Xu et al., 2002). This might result in a higher concentration of water-soluble hemicellulose ( $\mathrm{Xu}$ et al., 2007) after 
ensiling for the first-cut forage. Therefore, although wilting grass before ensiling restricts the fermentation of ensiled forage (Dawson et al., 1999), higher concentration of NFC in the directly cut grass silage made from the first-cut grass might be as a result of accumulation of NFC after degradation of structural carbohydrates by extensive fermentation. Concentrations of $\mathrm{NDF}$ and NFC in the second-cut grasses, however, were comparable before and after ensiling, and much more fermentation in the directly cut grass silage resulted in lower NFC concentration compared with that in the wilted silages.

As expected, the application of $L b$. plantarum to the grass silages resulted in a lower silage $\mathrm{pH}$ because homolactic acid bacteria often produce more lactic acid (Muck and Kung, 1997). The moderately higher $\mathrm{pH}$ in the grass silages treated with the combination of $L b$. plantarum and $L b$. buchneri was mainly due to the degradation of lactic acid into acetic acid by $L b$. buchneri (Oude Elferink et al., 2001) and the addition of Lb. buchneri to silages has generally resulted in a moderately higher pH (Kleinschmit and Kung, 2006; $\mathrm{Hu}$ et al., 2009). Previous research showed that silage $\mathrm{pH}$ increased as the DM content increased (Xiccato et al., 1994). Nevertheless, our results showed that with the increase in DM content, silage $\mathrm{pH}$ increased in the first-cut grass silages, but decreased in the second-cut grass silages, regardless of the decreases in total organic acid concentrations in both harvest silages. Response of silage $\mathrm{pH}$ to the forage DM content could probably be codetermined by concentrations of $\mathrm{NH}_{3}-\mathrm{N}$ (DM basis) and lactate in the ensiled forage because the ratio of lactate to $\mathrm{NH}_{3}-\mathrm{N}$ decreased in the first-cut silages and increased in the second-cut silages with the increase in forage DM (Figure 5).

Most of the $\mathrm{NH}_{3}-\mathrm{N}$ in silage results from protein degradation. Extensive proteolysis causes less efficient use of silage $\mathrm{N}$ by ruminants (Van Vuuren et al., 1995). In agreement with a previous report on grass silage (Driehuis et al., 2001), addition of LP+LB increased the concentration of $\mathrm{NH}_{3}-\mathrm{N}$ in the first-cut grass silages, whereas the combination of $L b$. plantarum and $L b$. buchneri had no effect on silage $\mathrm{NH}_{3}-\mathrm{N}$ concentration in the second-cut silages as was reported in corn silages (Filya, 2003a; Hu et al., 2009). It was proposed that the higher concentration of $\mathrm{NH}_{3}-\mathrm{N}$ as a result of inoculation with $L b$. buchneri might be associated with increased $\mathrm{pH}$ in Lb. buchneri-treated silage (Driehuis et al., 2001). Our results on effects of inoculants on silage $\mathrm{pH}$ and $\mathrm{NH}_{3}-\mathrm{N}$ concentration differed between the harvests of silages. The results might be attributed to the considerable difference in degrees of protein degradation that occurred in the first-cut and the second-cut grass silages as well as the difference in buffer capacity of the 2 harvest silages. It has been generally accepted that proteolysis in the ensiled forage is decreased at lower $\mathrm{pH}$ (McKersie, 1985; Jones et al., 1995). For unknown reasons, in spite of the lower $\mathrm{pH}$ in the LPtreated silage made from the first-cut grass, the $\mathrm{NH}_{3}-\mathrm{N}$ concentration was greater compared with the untreated silage. However, $\mathrm{NH}_{3}-\mathrm{N}$ concentration was lower in the LP-treated silage than the untreated silage made from second-cut grass.

Forage DM of silage adversely affects the degree of protein degradation (Muck, 1987; Jones et al., 1992). Nevertheless, silages with high CP concentration might restrict the decreasing degree of protein degradation as forage DM increased. Unlike the second-cut grass silage, no difference in $\mathrm{NH}_{3}-\mathrm{N}$ concentrations was observed when silage DM increased from 18 to $35 \%$ in the first-cut silage with high CP concentration (20\% DM).

Silages made from both harvests and treated with $\mathrm{LP}+\mathrm{LB}$ had lower concentrations of lactate and higher concentrations of acetate than untreated silage or LP-treated silage. These findings are in agreement with those of Driehuis et al. (2001), Filya (2003a,b), and $\mathrm{Hu}$ et al. (2009) with corn, sorghum, and grass silages. Because of the restricted fermentation in wilted silages (Dawson et al., 1999), lactate concentrations in untreated and LP-treated silages and acetate concentrations in untreated and both of the inoculanttreated silages decreased with the increase in forage DM content. However, our results showed increases in lactate in the LP+LB-treated silage as the forage DM increased (Figure 3). The heterofermentative bacteria Lb. buchneri is known to convert lactate to acetate and 1,2-propanediol under anaerobic conditions (Driehuis et al., 1999; Oude Elferink et al., 2001). Therefore, the increment in lactate concentration with the increase in

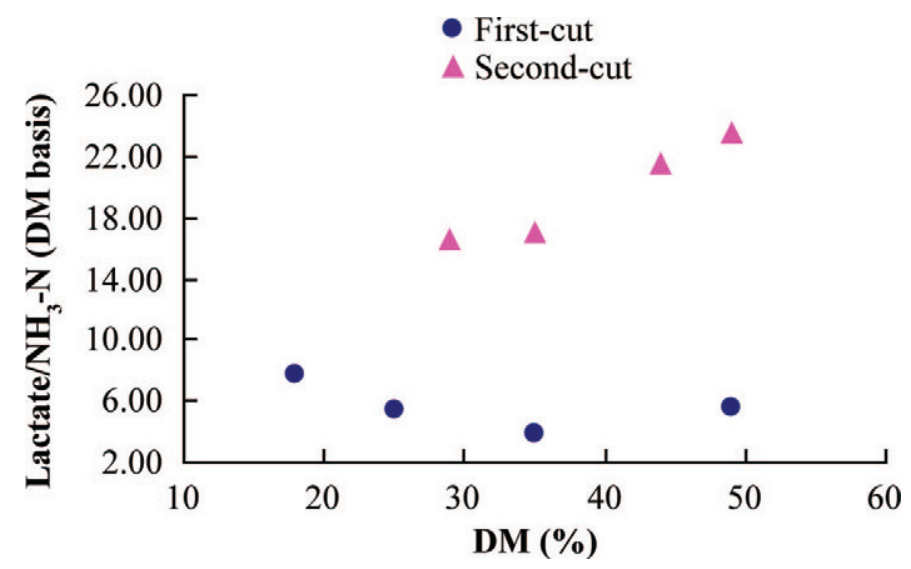

Figure 5. Responses of the ratios of lactate concentration to $\mathrm{NH}_{3}-\mathrm{N}$ concentration (DM basis) to the DM content in silages made from the first-cut $(\mathbf{0} \mathrm{n}=48)$ and second-cut $(\mathbf{\Lambda} ; \mathrm{n}=48)$ tall fescue and meadow fescue mixed crops. Color version available in the online PDF. 
forage $\mathrm{DM}$ in the $\mathrm{LP}+\mathrm{LB}$-treated silage indicates that conversion of lactate by $L b$. buchneri was restricted as forage DM increased.

Aerobic stability is of great importance because it is not only a potential cause of nutrient and DM losses, it also leads to health risks to animals and humans due to mycotoxins produced by undesirable microorganisms (Schmidt and Kung, 2010). Inoculation with Lb. buchneri has been reported to improve aerobic stability of ensiled forages (Muck, 1996). Although homolactic acid bacteria have sometimes led to poorer aerobic stability of silage (Weinberg et al., 1993; Filya 2003b), the results in the current study indicate that inoculation with $L b$. plantarum alone or in combination with $L b$. buchneri improved the aerobic stability of ensiled mixed-crop tall fescue and meadow fescue. An interaction between inoculation and forage DM on aerobic stability was detected in the current study. Based on the responses of aerobic stability to forage DM contents in the first-cut and second-cut grass silages, within the forage DM range of 18 to $44 \%$, aerobic stability of the ensiled grasses decreased as the forage DM increased. Therefore, wilted grass silages were not as aerobically stable as directly cut grass silages.

\section{CONCLUSIONS}

Inoculation with LP decreased silage $\mathrm{pH}$ and increased lactate concentration in the ensiled mixed-crop tall fescue and meadow fescue. Differences in fermentation profiles due to the addition of LP between the primary growth and the regrowth silages were small. The combination of $\mathrm{LP}$ with $\mathrm{LB}$ increased silage $\mathrm{pH}$ and the concentration of acetate in the ensiled grasses. Both inoculants increased the aerobic stability of the ensiled grasses, and the longest aerobic stability was detected on silages treated with the inoculant of LP+LB. Interactions existed between inoculation and forage DM on the fermentation profiles and aerobic stability of the ensiled forages. Wilting grass at different DM content restricted silage fermentation and subsequently decreased fermentation products compared with the directly cut grass silages. However, with the increase in forage DM, lactate concentration in the $\mathrm{LP}+\mathrm{LB}$-treated silage increased. Aerobic stability of grass mixes ensiled between 18 and 44\% DM increased as DM percentage increased, which suggests that directly cut grass silages were more aerobically stable than wilted grass silage, but LP and LP+LB inoculants improved aerobic stability of silages harvested between 18 and 44\% DM.

\section{REFERENCES}

Adesogan, A. T., N. Krueger, M. B. Salawu, D. B. Dean, and C. R. Staples. 2004. The influence of treatment with dual-purpose bacte- rial inoculants or soluble carbohydrates on the fermentation and aerobic stability of bermudagrass. J. Dairy Sci. 87:3407-3416.

AOAC. 1990. Official Methods of Analysis. 15th ed. Association of Official Analytical Chemists, Arlington, VA.

Brink, G. E., and M. D. Casler. 2009. Meadow fescue, tall fescue, and orchardgrass response to nitrogen application rate. Forage and Grazinglands 10.1094/FG-2009-0130-01-RS.

Broderick, G. A., and J. H. Kang. 1980. Automated simultaneous determination of ammonia and total amino acid in ruminal fluid and in vitro media. J. Dairy Sci. 63:64-75.

Campbell, C. P., and J. G. Buchanan-Smith. 1991. Effect of alfalfa grass silage dry matter content on ruminal digestion and milk production in lactating dairy cows. Can. J. Anim. Sci. 71:457-467.

Chatterton, N. J., P. A. Harrison, J. H. Bennett, and K. H. Asay. 1989. Carbohydrate partitioning in 185 accessions of Gramineae grown under warm and cool temperatures. J. Plant Physiol. 134:169174.

Dawson, L. E. R., C. P. Ferris, R. W. J. Steen, F. J. Gordon, and D. J. Kilpatrick. 1999. The effects of wilting grass before ensiling on silage intake. Grass Forage Sci. 54:237-247.

Driehuis, F., S. J. W. H. Oude Elferink, and S. F. Spoelstra. 1999. Anaerobic lactic acid degradation during ensilage of whole crop maize inoculated with Lactobacillus buchneri inhibits yeast growth and improves aerobic stability. J. Appl. Microbiol. 87:583-594.

Driehuis, F., S. J. W. H. Oude Elferink, and P. G. Van Wikselaar. 2001. Fermentation characteristics and aerobic stability of grass silage inoculated with Lactobacillus buchneri, with or without homofermentative lactic acid bacteria. Grass Forage Sci. 56:330-343.

Filya, I. 2003a. The effect of Lactobacillus buchneri and Lactobacillus plantarum on the fermentation, aerobic stability, and ruminal degradability of low dry matter corn and sorghum silages. J. Dairy Sci. 86:3575-3581.

Filya, I. 2003b. The effect of Lactobacillus buchneri, with or without homofermentative lactic acid bacteria, on the fermentation, aerobic stability and ruminal degradability of wheat, sorghum and maize silages. J. Appl. Microbiol. 95:1080-1086.

Haigh, P. M., D. G. Chapple, and T. L. Powell. 1996. Effect of silage additives on big-bale grass silage. Grass Forage Sci. 51:318-323.

Hall, M. B. 2000. Calculation of non-structural carbohydrate content of feeds that contain non-protein nitrogen. Univ. Florida Bulletin 339:A-25. Univ. Florida, Gainesville.

Hu, W., R. J. Schmidt, E. E. McDonell, C. M. Klingerman, and L. Kung Jr.. 2009. The effect of Lactobacillus buchneri 40788 or Lactobacillus plantarum MTD-1 on the fermentation and aerobic stability of corn silages ensiled at two dry matter contents. J. Dairy Sci. 92:3907-3914.

Jones, B. A., R. D. Hatfield, and R. E. Muck. 1995. Characterization of proteolysis in alfalfa and red clover. Crop Sci. 35:537-541.

Jones, B. A., R. E. Muck, and L. D. Satter. 1992. Influence of bacterial inoculant and substrate addition on alfalfa ensiled at different dry matter content. Grass Forage Sci. 47:19-27.

Kleinschmit, D. H., and L. Kung Jr. 2006. A meta-analysis of the effects of Lactobacillus buchneri on the fermentation and aerobic stability of corn and grass and small-grain silages. J. Dairy Sci. 89:4005-4013.

Kuoppala, K., M. Rinne, J. Nousiainen, and P. Huhtanen. 2008. The effect of cutting time of grass silage in primary growth and regrowth and the interactions between silage quality and concentrate level on milk production of dairy cows. Livest. Sci. 116:171-182.

McKersie, B. D. 1985. Effect of $\mathrm{pH}$ on proteolysis in ensiled legume forage. Agron. J. 77:81-86.

Muck, R. E. 1987. Dry matter level effects on alfalfa silage quality. I. Nitrogen transformations. Trans. ASAE 30:7-14.

Muck, R. E. 1996. A lactic acid bacteria strain to improve aerobic stability of silages. Pages $42-43$ in U.S. Dairy Forage Res. Center 1996 Res. Summaries. Madison, WI.

Muck, R. E., and J. T. Dickerson. 1988. Storage temperature effects on proteolysis in alfalfa silage. Trans. ASAE 31:1005-1009.

Muck, R. E., and L. Kung Jr. 1997. Effects of silage additives on ensiling. Pages 187-199 in Silage: Field to Feedbunk. NRAES-99. Northeast Regional Agricultural Engineering Service, Ithaca, NY. 
Oude Elferink, S. J. W. H., F. Driehuis, J. C. Gottschal, and S. F. Spoelstra. 1999. Anaerobic degradation of lactic acid to acetic acid and 1,2-propanediol, a novel fermentation pathway in Lactobacillus buchneri, helps to improve the aerobic stability of maize silage. Pages 266-267 in Proc. XII Int. Silage Conf. Swedish Univ. Agric. Sci., Uppsala, Sweden.

Oude Elferink, S. J. W. H., J. Krooneman, J. C. Gottschal, S. F. Spoelstra, F. Faber, and F. Driehuis. 2001. Anaerobic conversion of lactic acid to acetic acid and 1,2-propanediol by Lactobacillus buchneri. Appl. Environ. Microbiol. 67:125-132.

Romney, D. L., V. Blunn, R. Sanderson, and J. D. Leaver. 2000. Feeding behaviour, food intake and milk production responses of lactating dairy cows to diets based on grass silage of high or low drymatter content, supplemented with quickly and slowly fermentable energy sources. Anim. Sci. 71:349-357.

SAS Institute. 2004. SAS system software: Release 9.1 (TS1M3). SAS Institute Inc., Cary, NC.

Schmidt, R. J., and L. Kung Jr. 2010. The effects of lactobacillus buchneri with or without a homolactic bacterium on the fermentation and aerobic stability of corn silages made at different locations. J. Dairy Sci. 93:1616-1624.

Snedecor, G. W., and W. G. Cochran. 1980. Statistical Methods. 6th ed. Iowa State University Press, Ames.
Van Soest, P. J., J. B. Robertson, and B. A. Lewis. 1991. Methods for dietary fiber, neutral detergent fiber, and nonstarch polysaccharides in relation to animal nutrition. J. Dairy Sci. 74:3583-3597.

Van Vuuren, A. M., P. Huhtanen, and J. P. Dulphy. 1995. Improving the feeding and health value of ensiled forages. Pages 279-307 in Recent Developments in the Nutrition of Herbivores. Proc. 4th Intl. Symp. Nutr. Herbivores. M. Journet, E. Grenet, M. H. Farce, and M. Therie, ed. INRA Editions, Paris, France.

Weinberg, Z. G., G. Ashbell, Y. Hen, and A. Azrieli. 1993. The effect of applying lactic acid bacteria at ensiling on the aerobic stability of silages. J. Appl. Bacteriol. 75:512-518.

Xiccato, G., M. Cinetto, A. Carazzolo, and M. E. Cossu. 1994. The effect of silo type and dry matter content on the maize silage fermentation process and ensiling loss. Anim. Feed Sci. Technol. 49:311-323.

Xu, F., J. X. Sun, Z. C. Geng, C. F. Liu, J. L. Ren, R. C. Sun, P. Fowler, and M. S. Baird. 2007. Comparative study of water-soluble and alkali-soluble hemicelluloses from perennial ryegrass leaves. Carbohydr. Polym. 67:56-65.

Xu, S.-X., X.-Q. Zhao, P. Sun, T.-B. Zhao, W. Zhao, and B. Xue. 2002. A simulative study on effects of climate warming on nutrient contents and in vitro digestibility of herbage grown in QinghaiXizang Plateau. Acta Botanica Sinica 44:1357-1364. 